\title{
INFLUENCE OF VEHICLE PROCUREMENT ON THE VEHICLE FLEET ENERGY EFFICIENCY
}

\author{
Marko Stokić ${ }^{1}$, Mirjana Grdinić ${ }^{2}$, Davor Vujanović ${ }^{3}$ \\ ${ }^{1,3}$ University of Belgrade, Faculty of Transport and Traffic Engineering, Vojvode Stepe 305, 11000 Belgrade, \\ Serbia \\ 2 University of Montenegro, Faculty of Mechanical Engineering, Bul. Đorđa Vašingtona bb, 81000 \\ Podgorica, Montenegro
}

Received 17 November 2017; accepted 3 January 2018

\begin{abstract}
In this paper, the vehicle procurement is considered as a factor which influences the vehicle fleets energy efficiency. Vehicle fleet managers in transport and logistics companies with their own fleet for freight transport often make a decision to procure an appropriate vehicle. In this sense, the vehicle procurement represents a significant activity for increasing the vehicle fleets energy efficiency. During a process of decision making in order to purchase an appropriate vehicle, managers take into consideration a number of different criteria. Based on the literature review, as well as on the basis of the author's own experience, the relevant criteria that have the significance on making the observed decision are defined in the paper. It is shown how the defined vehicle procurement criteria affect the increasing of vehicle fleet energy efficiency, as well as the reduction of the transport and maintenance costs. In order to make the right decision when purchasing a vehicle, managers need to take into consideration all defined criteria. This contributes to increasing of the vehicle fleet energy efficiency and reducing transportation and maintenance costs, thereby generating greater profit in the observed companies.
\end{abstract}

Keywords: energy efficiency, vehicle procurement, criteria, vehicle fleet.

\section{Introduction}

Transport and logistics companies with their own freight transport vehicle fleets are observed in this paper. In order to maximize their profit, the companies aim to realize all planned transport tasks during observed period, with lowest total transport and maintenance costs. To achieve the defined goal, the managers in the observed companies are trying to increase the energy efficiency of the vehicle fleet (Vujanović et al., 2010). One way to increase energy efficiency is the application of integrated fleet maintenance management (Vujanović et al., 2017). In order to increase the energy efficiency of vehicle fleets, various improvement measures have been applied over the past several decades, which can be divided into three groups: 1) engine improvements and emission regulations; 2) non-engine technological improvements on the vehicle and changes in the fleet composition; 3) operational measures (Federal Railroad Administration, 2009). In that sense, with using the Exhaust gas recirculation system, in the first decade of the 21 st century, fuel consumption decreased by an additional 6\% (Federal

${ }^{1}$ Corresponding author: m.stokic@sf.bg.ac.rs 
Railroad Administration, 2009). (Saricks et al., 2003) point out that aerodynamic devices on the vehicle can increase energy efficiency. Besides that, higher energy efficiency can be achieved by reducing the vehicle weight (Maintenance Council, 1998), as well as using wide-based tires instead of using double wheels (Federal Railroad Administration, 2009). According to (Liimatainen \& Pöllänen, 2010), the increase in energy efficiency can be also achieved by optimizing the utilization of vehicles and choosing the right vehicle size and type. Operational measures for improving energy efficiency include the application of modern information technologies (McKinnon, 1999). It is important to point out that the improvements from the category of nonengine technological improvements on the vehicle and changes in the fleet composition and operational measures are very important for vehicle fleet managers.

Besides efficient vehicle fleet maintenance management, the considered companies are encountered with the necessary renewal of their vehicle fleets. Since the vehicles causing an increase of transportation and maintenance costs after a certain period of their exploitation, vehicle fleet renewal is one of the most important activities for vehicle fleet operation management effectiveness. Besides that, the insufficiently good choice of vehicles during the procurement process can also increase transport and maintenance costs, which results with a company profit reduction.

In order to make the right decision during a vehicle procurement process, managers have to consider several different criteria. Regarding to this, the criteria that should be considered for the decision making process are defined in this paper. This contributes to the increase of the vehicle fleet energy efficiency and to the total transport and maintenance costs reduction for a given transport volume, which enabling the observed companies to achieve the defined goal.

The paper is structured as follows. The chapter 2 describes the vehicle procurement activity and shows the increase in the number of commercial vehicles in several developed countries, as well as in the Republic of Serbia. Literature review regarding the aspects that are considered during vehicle procurement process is presented in chapter 3. Based on the literature review and the author's own experience, chapter 4 defines the relevant criteria that have to be considered during vehicle purchasing, which are classified into several interdependent groups. The conclusion and future research are given in chapter 5.

\section{Vehicle Procurement}

The vehicle procurement represents one of the basic activities of vehicle fleet operation management and key preconditions for the efficient transport system operation, i.e. costeffective usage, availability, maintenance and environmental sustainability of vehicles (Manojlović, 2012). The vehicle procurement represents a complex task for a vehicle fleet manager. The manager should decide is it economically justified to purchase another, newer vehicle. Old vehicles are energetically less efficient and cause higher transportation and maintenance costs, while the procurement of a new vehicle causes major initial costs due to the price of a new vehicle, but leads to an increase of energy efficiency and to lower transportation and maintenance costs. In this sense, during the vehicle procurement process it is necessary to follow the following steps (Milović \& Manojlović, 2015): determining the actual needs for vehicles, defining the technical specification and contract elements 
for vehicles, determining the best bid, selecting the best bidder, managing the contract in the contract period, establishing partnerships with the vehicle supplier. According to the author (Manojlović, 2012), the vehicle procurement process can be carried out through: purchasing vehicles in cash (vehicles are owned by the company), financial leasing (in the contract period the vehicles are not owned by the company), business or operating leasing (longterm vehicle lease form) and a combination of these three cases.

In the last few years there was an increase in the number of new registered lorries and road tractors in European countries and therefore an increase in the total number of vehicles of this type. In this sense, vehicle fleet managers in European logistic and transport companies are more and more in the process of own vehicle fleet renewal, i.e. the vehicle procurement process. Figure 1 shows four selected countries that have constant linear growth in term of the total number of lorries and road tractors in the period from 2009 to 2015 (2015 is the last year for which data is available). The selected countries are Germany (Central Europe), Poland (Eastern European), United Kingdom (Western European) and Turkey (representing Balkan countries). In 2015, all of these countries had around 3 million vehicles and a constant linear trend of increase in the total number of observed vehicles. As can be seen from the figure 1, Turkey has the highest growth percentage from 2009 to 2015 (an increase of $38 \%$ ). Since there has been a steady growth over the past 7 years, it can be expected that this trend will continue in the coming years.

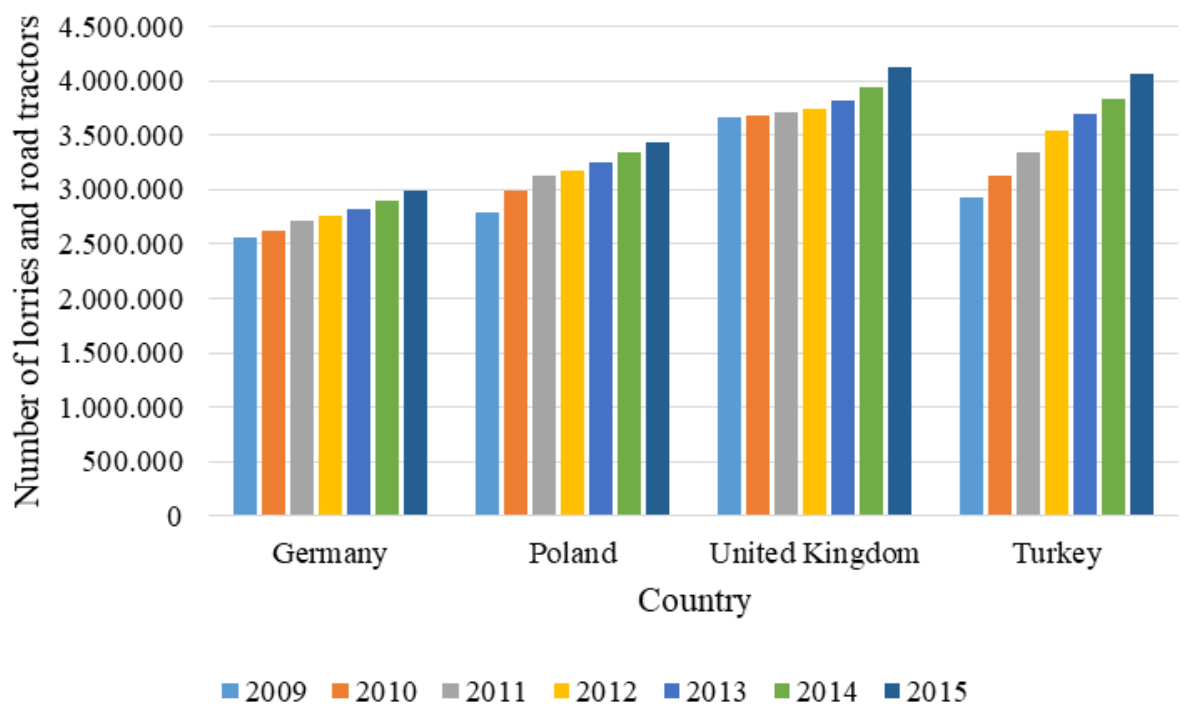

Fig. 1.

The Trend of Growth in the Total Number of Registered Lorries and Road Tractors in Germany, Poland, United Kingdom and Turkey from 2009 to 2015

Source: (Eurostat, 2017; Turkish statistical institute, 2017; Kraftfahrt-Bundesamt, 2017) 
In the case of the Republic of Serbia, from the figure 2, we can see the growing trend of registered lorries and road tractors in the period from 2009 to 2016 , with the minor anomalies with the growing trend in 2013 and 2014. In that sense, in 2016, over 2 million road tractors and lorries were registered (Figure 2). As well as with the
Turkey, there is an increase of $38 \%$, but in this case, compared years are 2016 and 2009. Based on the presented trend, it can be concluded that the vehicle fleet managers in the Republic of Serbia will have more and more vehicle procurement tasks and on the basis of that, they will be able to apply the criteria that are presented in this paper.

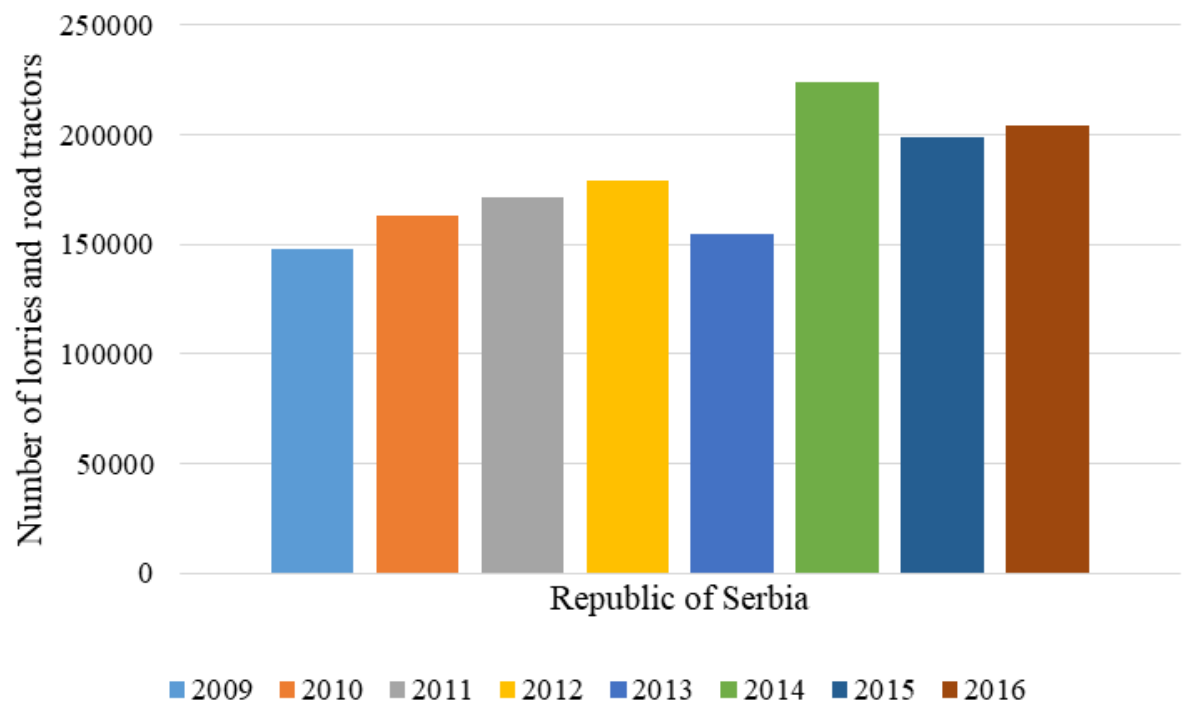

Fig. 2.

Number of Registered Lorries and Road Trucks in the Republic of Serbia from 2009 to 2016 Source: (Statistical Office of the Republic of Serbia, 2017)

Besides that, it should be noted that vehicle fleet managers in observed companies except conventional (fossil-fuel) vehicles are increasingly choosing to buy alternative fuel vehicles (electric, hybrid, fuel cells, etc.). Regarding to this, in the last few years there has been an increase in the number of alternative fuel powered vehicles. On this fact significantly contribute the benefits and subsidies which company receives from the state if it uses alternative fuel powered vehicles. There are some public transport companies which have replaced entire conventional vehicle fleet with environmentally friendly vehicles (Nicolas et al., 2014). Also, electric vehicles are four times cheaper to use and easier to maintain than conventional diesel-powered vehicles (Feng et al., 2013), but, the price of a new electric vehicle is three times higher. If there are no subsidies from the state, the high price is one of the main factors why vehicle fleet managers do not decide to purchase electric vehicles. Alternative forms of energy used by a vehicle can be liquefied petroleum gas (LPG), electrical energy, bioethanol, 
biodiesel, compressed natural gas (CNG), liquefied natural gas (LNG) and others. Besides vehicles which only use one type of energy (alternative or conventional), there are also vehicles which use a combination of the mentioned types, the so-called hybrids.

Besides the price of vehicles, there are many other criteria that fleet managers consider when deciding on the choice of a suitable vehicle in the procurement process. Regarding to this, the next chapter gives a literature review from the observed area.

\section{Literature Review}

In this chapter is given a literature review of the papers from the other authors who dealt with the vehicle procurement problem and the criteria that need to be considered in order to successfully solve this problem. At the very end of the chapter, a table with the authors' names, their papers and criteria which they have identified as essential in term of vehicle procurement has been shown.

(Bakkehaug et al., 2014) in their paper dealt with a strategic fleet renewal problem in shipping, they state that shipping companies in most cases have heterogeneous fleets (which is the same case with vehicle fleets of transport and logistics companies). Also, they lists the criteria that must be considered during vehicle procurement process: demand and supply of vessels on the secondhand market, capacity at the wharfs, demand for charter vessels, charter rates, spot cargo demand, spot cargo rates, operating costs, available capital for investment, cost of buying a secondhand vessel, cost of buying a new vessel, cost of one voyage, demand in units of spot cargo, income per unit carried on the spot market, the number of voyages that must be sailed, maximum number of voyages, capacity, selling price, scrap rate. As fleet managers have the ability to choose a new or used vehicle into their fleet, (Morch et al., 2017) point out that the company should only think about the procurement of a new vehicles. Also, these authors state that the most important role in purchasing new vessels is the analysis of the allocation assignment to the vessels, which allows the temporary fleet adjustment and the use of the available fleet. According to the (OECD/ ITF, 2011), the vehicle procurement process must be observed through the vehicle safety, age, emissions and cost efficiency criteria.

(Fourie, 2010) as the criteria for vehicle procurement lists the initial purchase price, the costs of modifications to equip the vehicle to be able to perform the job, the running cost (fuel) and maintenance cost. Another variables that plays a determining factor in the vehicle selection is the type of fleet discount on initial purchase that the vendor can offer. (Nicolas et al., 2014) use criteria such as sustainable mobility (social, economic and environmental) and the environmental impact of vehicles. (McDaniel et al., 2009) emphasize the vehicles compatibility, reliability, fuel efficiency, environmental level of the vehicle, warranty, procurement costs determined by state contracts, vehicle lifetime, relationship with vehicle manufacturer (does the manufacturer provide good customer support), development and availability of sales network and the value of the used vehicles. (Vujanović et al., 2010) state that managers should take into consideration the criterion "adaptability of the vehicle's cargo space to transport requirements" in order to increase the utilization of the vehicles useful load capacity, which increasing the vehicle fleet energy efficiency. 
As it is mentioned earlier, alternative vehicles increasingly taking part in transport and logistics companies across Europe. Regarding to that, some authors observed criteria that should be taken into consideration during alternative vehicle procurement process. (Lin et al., 2009), dealt with the vehicle energy efficiency and they have listed five class criteria which should be considered during procurement of vehicles on alternative fuel. Those criteria are: safety (leak safety, fuel ignition safety, refuel safety, in vehicle fuel storage safety, storage safety) environmental pollution (air pollution, noise pollution, leak pollution, discard pollution), vehicle performance (cruising range, refuel rate, horsepower, torque, fuel efficiency), accessibility (fuel accessibility, accessibility in usage, maintenance accessibility), costs (repair cost, maintenance cost, fuel cost, new vehicle cost). (Ansaripoor et al., 2014) defined the fuel price, the average electricity charge cost of electric vehicles (EVs) batteries for 100 kilometers, running cost for (EVs) per 100 kilometers, total investment (fixed) cost for fossil fuel technologies, total investment (fixed) cost for EVs.

Regarding decision making in air transport, Karagulle (2012) points out an example of a Turkish airline company. On basis of that company and new aircraft procurement, he lists criteria such as: the compatibility of a new vehicle with the existing fleet and the aircraft cost and selection of the supplier (minimizing maintenance costs) as the main criteria. Other observed parameters applied by the mentioned company are: production date, vehicle comfort, new technologies existence, safety and damage tolerance level.

Table 1.

Observed Criteria Presented by Authors and Their Papers

\begin{tabular}{|c|c|c|c|}
\hline Authors & Year & Paper & Criteria \\
\hline $\begin{array}{l}\text { Bakkehaug R. } \\
\text { Eidem E. S. } \\
\text { Fagerholt K. } \\
\text { Hvattum L. M. }\end{array}$ & 2014 & $\begin{array}{l}\text { A stochastic programming } \\
\text { formulation for strategic fleet } \\
\text { renewal in shipping }\end{array}$ & $\begin{array}{l}\text { demand and supply of vessels on the secondhand market } \\
\text { cost of buying a secondhand vessel } \\
\text { cost of buying a new vessel } \\
\text { cost of one voyage } \\
\text { capacity at the wharfs } \\
\text { demand for charter vessels } \\
\text { charter rates } \\
\text { spot cargo demand and rates } \\
\text { operating costs } \\
\text { available capital for investment } \\
\text { demand in units of spot cargo } \\
\text { income per unit carried on the spot market } \\
\text { the number of voyages that must be sailed } \\
\text { maximum number of voyages } \\
\text { capacity } \\
\text { selling price } \\
\text { scrap rate }\end{array}$ \\
\hline $\begin{array}{l}\text { Morch O. } \\
\text { Fagerholt K. } \\
\text { Pantuso G. } \\
\text { Rakke J. }\end{array}$ & 2017 & $\begin{array}{l}\text { Maximizing the rate of return } \\
\text { on the capital employed in } \\
\text { shipping capacity renewal }\end{array}$ & $\begin{array}{l}\text { only new vehicles procurement } \\
\text { analysis of the allocation assignment to the vessels }\end{array}$ \\
\hline OECD/ITF & 2011 & $\begin{array}{l}\text { Car Fleet Renewal Schemes: } \\
\text { Environmental and Safety } \\
\text { Impacts }\end{array}$ & $\begin{array}{l}\text { vehicle safety } \\
\text { vehicle age } \\
\text { emissions } \\
\text { cost efficiency }\end{array}$ \\
\hline
\end{tabular}




\begin{tabular}{|c|c|c|c|}
\hline Authors & Year & Paper & Criteria \\
\hline $\begin{array}{l}\text { Lin C-W. } \\
\text { Chen S-H. } \\
\text { Tzeng G-H. }\end{array}$ & 2009 & $\begin{array}{l}\text { Constructing a cognition map } \\
\text { of alternative fuel vehicles } \\
\text { using the DEMATEL method }\end{array}$ & $\begin{array}{l}\text { safety (leak safety, fuel ignition safety, refuel safety, in } \\
\text { vehicle fuel storage safety, storage safety) } \\
\text { environmental pollution (air pollution, noise pollution, } \\
\text { leak pollution, discard pollution) } \\
\text { vehicle performance (cruising range, refuel rate, } \\
\text { horsepower, torque, fuel efficiency) } \\
\text { accessibility (fuel accessibility, accessibility in usage, } \\
\text { maintenance accessibility) } \\
\text { costs (repair cost, maintenance cost, fuel cost, new } \\
\text { vehicle cost) }\end{array}$ \\
\hline $\begin{array}{l}\text { Ansaripoor A. H. } \\
\text { Oliveira F.S. } \\
\text { Liret A. }\end{array}$ & 2014 & $\begin{array}{l}\text { A risk management system for } \\
\text { sustainable fleet replacement }\end{array}$ & $\begin{array}{l}\text { fuel price } \\
\text { average electricity charge cost of electric vehicles (EVs) } \\
\text { batteries for } 100 \text { kilometers } \\
\text { running cost for (EVs) per } 100 \text { kilometers } \\
\text { total investment (fixed) cost for fossil fuel technologies } \\
\text { total investment (fixed) cost for EVs }\end{array}$ \\
\hline Fourie P. & 2010 & $\begin{array}{l}\text { Development of a fleet } \\
\text { vehicle replacement strategy }\end{array}$ & $\begin{array}{l}\text { initial purchase price } \\
\text { costs of modifications to equip the vehicle to be able to } \\
\text { perform the job } \\
\text { fuel cost } \\
\text { maintenance cost } \\
\text { possible purchase discount }\end{array}$ \\
\hline $\begin{array}{l}\text { Nicolas D. S. } \\
\text { Colomer O. } \\
\text { Fiore M. } \\
\text { Colomer J. V. }\end{array}$ & 2014 & $\begin{array}{l}\text { Restructuring of public } \\
\text { transport service of Alcoy }\end{array}$ & $\begin{array}{l}\text { sustainable mobility (social, economic and } \\
\text { environmental) } \\
\text { environmental impact of vehicles }\end{array}$ \\
\hline $\begin{array}{l}\text { McDaniel J. L. } \\
\text { Kelly C. } \\
\text { Martin S. } \\
\text { Leznoff J. A. }\end{array}$ & 2009 & Vehicle replacement policy & $\begin{array}{l}\text { vehicles compatibility, } \\
\text { vehicle reliability } \\
\text { fuel efficiency } \\
\text { environmental level of the vehicle } \\
\text { warranty } \\
\text { procurement costs determined by state contracts } \\
\text { vehicle lifetime } \\
\text { relationship with vehicle manufacturer (does the } \\
\text { manufacturer provide good customer support) } \\
\text { development and availability of sales network } \\
\text { value of the used vehicles }\end{array}$ \\
\hline Karagulle A.O. & 2012 & $\begin{array}{l}\text { The evaluation of fleet } \\
\text { structures in Turkish aviation } \\
\text { industry from strategic } \\
\text { management point of view }\end{array}$ & $\begin{array}{l}\text { compatibility of a new vehicle with the existing fleet } \\
\text { cost of aircraft } \\
\text { selection of the supplier } \\
\text { maintenance costs } \\
\text { production date } \\
\text { vehicle comfort } \\
\text { new technologies existence } \\
\text { safety } \\
\text { damage tolerance level }\end{array}$ \\
\hline $\begin{array}{l}\text { Vujanović D. } \\
\text { Mijailović R. } \\
\text { Momčilović V. } \\
\text { Papić V. } \\
\end{array}$ & 2010 & $\begin{array}{l}\text { Energy efficiency as a } \\
\text { criterion in the vehicle fleet } \\
\text { management process }\end{array}$ & $\begin{array}{l}\text { adaptability of the vehicle's cargo space to transport } \\
\text { requirements }\end{array}$ \\
\hline
\end{tabular}

\section{Based on the literature review, it is possible} to distinguish several criteria that are crucial in the vehicle procurement process.
All mentioned criteria can be classified into several groups, and these groups are explained in more detail in the next chapter. 


\section{Criteria Classification}

Within this chapter, the criteria that should be considered during vehicle procurement process are classified. Some of those criteria are the vehicle price, fuel type (diesel, alternative fuels, electricity), maintenance costs, safety, the warranty period and coverage, capacity (useful vehicle load), the price of a used vehicle (when the company decides to sell its own vehicle), and similar. All these criteria affect the transport and maintenance costs and some of them are closely related to the vehicle / fleet energy efficiency.

Based on the literature review and the author's own experience, authors classified mentioned criteria into four groups. The first group includes vehicle constructional criteria. Fleet managers must define which type of vehicle construction is required in order to satisfy the company's business character, or what vehicle characteristics are needed in order to successfully carry out the transport requirements. This group includes criteria as vehicle engine power, capacity, adjustment to loading and unloading operations, propulsion type, etc. The second group of criteria includes the initial vehicle procurement costs (new and used vehicle price). These criteria serve to select a vehicles which price is within the planned budget for the vehicle procurement. The third group of criteria that should be observed are the exploitation criteria, i.e., the vehicle age, the manufacturer's warranty period, the vehicle maintenance cost (in the warranty period), coverage of maintenance service centers, the vehicle maintenance costs (when the vehicle is not in the warranty period) fuel efficiency, fuel availability, spare parts availability, the existence of modern on-board systems which increase safety and energy efficiency (one of the systems that affect safety is the Forward Collision Warning System, which anticipates and reacts in order to prevent traffic accidents, while the systems which have influence on the increase in energy efficiency include different eco-driving systems that provide active driver support in real time (while driving). And the last group, post-exploitation criteria, includes the vehicle and its parts recyclability, as well as the price of a used vehicle in the case of resale. The mentioned groups of criteria and criteria themselves, as well as their interdependence are shown in Figure 3.

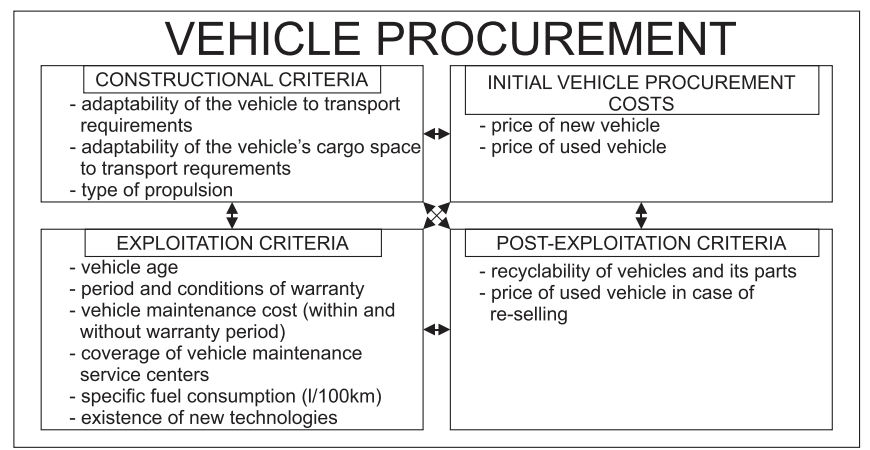

Fig. 3.

Relevant Criteria which should be taken into Consideration during Vehicle Procurement Process divided into Four Groups 
All criteria have some impact either on transport cost, maintenance costs or energy efficiency. Some criteria may have an impact on all three above mentioned groups. For example, constructional criteria, such as engine power and the vehicle and its load compartment adaptability to transport requirements, have a direct impact on transport costs, and the energy efficiency. Also, it is important to point out that the fleet managers should take into consideration vehicle dimensions and its mass, because both have impact on fuel consumption and due that impact on transport costs and energy efficiency.

Vehicle price criterion (new or used vehicle) can be classified as a criterion that has an impact on transport costs. Due to their specificity, the costs based on this criterion are reducing by increasing the traveled mileage. The costs caused by this criterion are proportionate to the procurement cost and the traveled mileage after the vehicle purchase. Regarding to this, this criterion has the greatest impact at the very beginning of the vehicle exploitation.

The third, and perhaps the most important group is exploitation criteria. These criteria have a major impact on transportation and maintenance costs and also on the vehicle energy efficiency. The vehicle age, which is within this group, significantly influences the mentioned costs and energy efficiency. Let's look at the vehicles of the same manufacturer and type and different years of age. It is a logical assumption that the older vehicle will have higher fuel consumption due to the exploitation of its assemblies, as well as the higher maintenance costs due to the higher failure frequency, and thus that vehicle is less energy efficient. Besides this criterion, the length of the manufacturer's warranty plays an important role in vehicle selecting. During vehicle selection process, for the fleet managers is very important to know the length of the warranty period so they can plan vehicle maintenance. Regarding to this, the preventive interventions frequency is also important for fleet managers so they can know after how many kilometers or months they have to send their vehicle to the preventive maintenance, as well as the preventive maintenance cost, warranty on certain parts (free repair in case of failure), etc. As these criteria are related to the vehicle maintenance, they also have a direct impact on maintenance costs. The vehicle fleet managers should also consider the criterion of vehicle repair costs after the warranty period. If parts for some vehicles are too expensive, this significantly can have influence on total maintenance costs, especially because the period of vehicles usage out the warranty period is much longer than during the warranty period. In this sense, managers can choose a vehicle manufacturer that offers better terms and conditions within the warranty period, but afterwards maintenance costs can be significantly higher, which ultimately results in higher overall maintenance costs (of course, assuming that the vehicle is maintained in an authorized vehicle manufacturer service center). Criteria from this group which are closely connected are the fuel consumption $(1 / 100 \mathrm{~km})$ and fuel price. Both criteria have an impact on transport costs, and have a significant impact on the vehicle energy efficiency. The close connection between these criteria is reflected in the fact that the overall cost of fuel consumption is the product of the spent fuel and its price per liter. In this sense, it doesn't necessarily mean that less fuel consumption will result 
with lower overall fuel cost, if the price of this fuel type is significantly higher, and vice versa. From the energy efficiency aspect it is necessary to use alternative types of propulsion, such as electricity, fuel cells, etc. And at the very end, but not less important, this group includes criteria which are related to the existence of modern on-board systems which have influence on the increase of safety and energy efficiency. Reduced number of traffic accidents leads to lower maintenance costs. Besides anticollision systems there are also modern on-board systems which help drivers to achieve lower fuel consumption and thus increase energy efficiency.

The criteria from the fourth group are the used vehicle price (re-sale) and the vehicle and its parts recyclability. These criteria affect the transportation costs as well as the earlier mentioned price criterion, only in this case in the benefit of managers (when the vehicle is sold, the final total transport cost per kilometer is reduced). The money from re-selling and recycling can be invested in the procurement of the new vehicle.

From the previous it can be noticed that a large number of criteria have an impact on the energy efficiency of vehicles, and fleets. Energy efficiency is closely related to transport costs. Increasing transport costs, or increasing fuel consumption, the energy efficiency is reduced. In this sense, we can say that the energy efficiency of a vehicle fleet is inversely proportional to the overall transport cost of vehicle fleet. An increase in transport costs affects the reduction of energy efficiency, i.e. it can be said that the correlation between these parameters is negative. Low transport costs correspond to a high value of energy efficiency and vice versa.
Transport and logistics companies can achieve the energy efficiency of their own vehicle fleets through the procurement of vehicles that possess technological improvements on the engine such as: compressed air injection, selective catalytic reduction - SCR, exhaust gas recirculation - EGR, common rail injection systems, alternative propulsion vehicles and etc. Besides this fleet managers should consider procurement of vehicles which have aerodynamic devices (on the cab, between the cab and the trailer / semi-trailer, between the axles and on the end of the trailer / semi-trailer) and vehicles that have tires with low rolling resistance. Also, vehicles made of light materials have a lower own mass, and therefore it is possible to achieve an increase in the vehicle capacity, which increases energy efficiency. In terms of operational activities, fleet managers can achieve an increase in energy efficiency by purchasing a vehicle from a manufacturer who offers free eco-driving training as well as vehicles with modern systems (e.g. tire pressure monitoring system - TPMS, ecodriving dashboard, adaptive cruise control - ACC, etc.).

Since the criteria do not have the same importance (weight) for the fleet managers, in order to make the best decision during the vehicle procurement process it is necessary to rank the criteria by relevance. This is possible to realize by applying the multiple-criteria decision making method. Although the criteria are different and divided into different groups, they are mutually dependent, i.e. the criterion from one group can affect one or more criteria from the other group (e.g. the vehicle price is influenced by the vehicle equipment and existence of modern technologies, engine power, load capacity and etc.). 


\section{Conclusion}

This paper examines the criteria on which companies with their own vehicle fleet can successfully carry out the vehicle procurement process and fleet renewal. By choosing an appropriate vehicle, the company reduces its transportation and maintenance costs, thereby increase its profit and competitiveness on the market. The authors defined four basic groups of criteria: vehicle construction criteria, initial vehicle procurement costs criteria, vehicle exploitation criteria and post-exploitation criteria. Each criterion has either impact on transport costs, maintenance costs or energy efficiency. Some of the criteria can have multiple impacts (a combination of the aforementioned impacts). In this sense, the transport costs are influenced by the criteria of vehicle engine power, load capacity, vehicle and load compartment suitability to the transport requirements, vehicle price, vehicle age, coverage of maintenance service centers, specific fuel consumption, fuel price, existence of modern on-board systems, vehicle and its parts recyclability, the price of used vehicle (re-selling). Due to the close connection between transport costs and energy efficiency, the criteria that have an impact on energy efficiency include all the aforementioned criteria, except recyclability and the prices of new and used vehicles and fuel price. Besides the vehicle age and the existence of modern on-board systems criteria (which affect all groups), the manufacturer's warranty period, warranty conditions, vehicle maintenance costs (in and out of the warranty period) and the availability of spare parts have a direct impact on maintenance costs. The mentioned criteria have interdependent impact and affect differently the vehicle procurement process and the fleets energy efficiency. Since not all criteria have the same relative weights, this represents a classic example of Multiple-Criteria Decision Making (MCDM). Regarding to this, the subject of further research will be a determination of the criteria relative weights and application of some MCDM methods, as well as concrete example of the successfully applied multi-criteria decision making method in vehicle procurement process in one or more transport and logistics companies in the Republic of Serbia.

\section{Acknowledgements}

The research in this paper has been realized within the project TR36027 named: "Software development and national database for strategic management and development of transportation means and infrastructure in road, rail, air and inland waterways transport using the European transport network models" supported by the Ministry of Education, Science and Technological Development of the Republic of Serbia.

\section{References}

Ansaripoor, A. H.; Oliveira, F.S.; Liret, A. 2014. A risk management system for sustainable fleet replacement, European Journal of Operational Research 237(2): 701-712.

Bakkehaug, R.; Eidem, E. S.; Fagerholt, K.; Hvattum, L. M. 2014. A stochastic programming formulation for strategic fleet renewal in shipping, Transportation Research Part E 72: 60-76.

Eurostat. 2017. Stock of vehicles \& Stock of vehicles (historical data). Available from internet: <http:// ec.europa.eu/eurostat/web/transport/data/database $>$. 
Federal Railroad Administration. 2009. Comparative Evaluation of Rail and Truck Fuel Efficiency on Competitive Corridors. Final Report of Federal Railroad Administration, Washington D.C., USA. 156 p.

Feng, W.; Figliozzi, M. 2013. An economic and technological analysis of the key factors affecting the competitiveness of electric commercial vehicles: A case study from the USA market, Transportation Research Part C26: 135-145.

Fourie, P. 2010. Development of a fleet vehicle replacement strategy. Bachelors of Industrial Engineering. Faculty of Engineering, Built Environment and Information Technology, University of Pretoria. Pretoria. 44 p.

Karagulle, A. O. 2012. The evaluation of fleet structures in Turkish aviation industry from strategic management point of view, Procedia - Social and Behavioral Sciences 58: 93-97.

Kraftfahrt-Bundesamt. 2017. Fahrzeugklassen und Aufbauarten. Available from internet: <https:// www.kba.de/DE/Statistik/Fahrzeuge/Bestand/ FahrzeugklassenAufbauarten/fahrzeugklassen_node. html>.

Liimatainen, H.; Pöllänen, M. 2010. Trends of energy efficiency in Finnish road freight transport 1995-2009 and forecast to 2016, Energy Policy 38(12): 7676-7686.

Lin, C-W.; Chen, S-H.; Tzeng, G-H. 2009. Constructing a cognition map of alternative fuel vehicles using the DEMATEL method, Journal of multi-criteria decision analysis 16(1-2): 5-19.

Maintenance Council; American Trucking Associations. 1998. The Fleet Manager's Guide to Fuel Economy: A Comprehensive Guide to Improving Commercial Vehicle Fleet Fuel Efficiency. Report of American Trucking Association, Alexandria, Virginia, USA. 60 p.
Manojlović, A. 2012. Public companies fleet cost efficiency management. Doctoral Dissertation. University of Belgrade, Faculty of transport and traffic engineering, Belgrade. 182 p.

McDaniel, J. L.; Kelly, C.; Martin, S.; Leznoff, J. A. 2009. Vehicle replacement policy - Annex 13. Supplemental Instructions Regarding Legislative Budget Request (LBR). Instructions for Fiscal Year 2010-11. The Department of Management Services. Florida, USA. 21 p.

McKinnon, A. 1999. A Logistical Perspective on the Fuel Efficiency of Road Freight Transport. Report on the Workshop "Improving Fuel Efficiency in Road Freight: The Role of Information Technologies", International Energy Agency and European Conference of Ministers of Transport, Paris, France. 27 p.

Milović, S.; Manojlović, A. 2015. Kriterijumi i modeli za nabavku proizvoda i usluga u transportu. Zbornik radova sa naučno stručnog skupa „Ka održivom transportu 2015“, 137-151.

Morch, O.; Fagerholt, K.; Pantuso, G.; Rakke, J. 2017. Maximizing the rate of return on the capital employed in shipping capacity renewal, Omega 67: 42-53.

Nicolas, D. S.; Colomer, O.; Fiore, M., Colomer, J. V. 2014. Restructuring of public transport service of Alcoy, Procedia-Social and Behavioral Sciences 160: 410-419.

OECD/ITF. 2011. Car Fleet Renewal Schemes: Environmental and Safety Impacts. Report. 72 p.

Saricks, C.; Vyas, A.; Stodolsky, F.; Maples, J. 2003. Fuel Consumption of Heavy-Duty Trucks: Potential Effect of Future Technologies for Improving Energy Efficiency and Emissions, Transport Research Record 1842: 9-19

Statistical Office of the Republic of Serbia. 2017. Registered road motor vehicles and trailers and road traffic accidents. Available from internet: 
<http://www.stat.gov.rs/WebSite/Public/ PageView.aspx? Key $=431$ \& URL $=$ http: $/ /$ pod 2 . stat.gov.rs/ElektronskaBiblioteka2/Pretraga. asp $x$ ?pubType $=3 \% 26$ areaId $=15>$.

Turkish statistical institute. 2017. Road motor vehicles. Available from internet: <http://www.turkstat.gov.tr/ PreTablo.do?alt_id=1051>.
Vujanović, D.; Mijailović, R.; Momčilović, V.; Papić, V. 2010. Energy efficiency as a criterion in the vehicle fleet management process, Thermal Science 14(4): 865-878.

Vujanović, D.; Momčilović, V.; Medar, O. 2017. Influence of an integrated maintenance management on the vehicle fleet energy efficiency, Thermal Science (in print). doi: 10.2298/TSCI170209122V. 